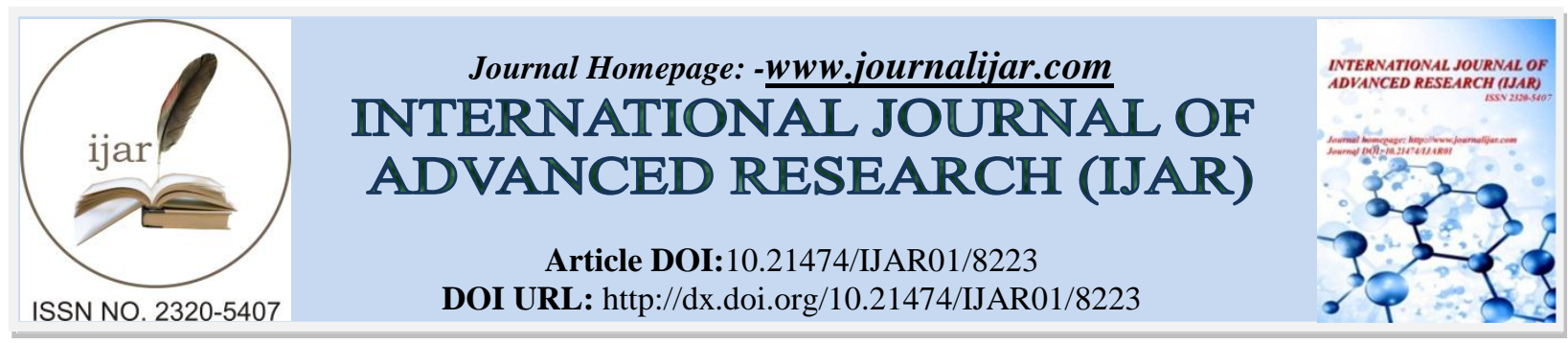

RESEARCH ARTICLE

\title{
EFFECT OF POLYHERBAL FORMULATION IN THE MANAGEMENT OF SCABIES (PAMA) - A CASE REPORT.
}

Vishal Prajapati ${ }^{1}$, Sonam Chaudhary ${ }^{2}$, Kuldeep Kumar Soni ${ }^{3}$, V. K. Kori ${ }^{4}$ and K. S. Patel ${ }^{5}$.

1. PhD Scholar, Kaumarbhritya Department, IPGT \& RA, Jamnagar, Gujarat, India.

2. MD Scholar, Kaumarbhritya Department, IPGT \& RA, Jamnagar, Gujarat, India.

3. Lecturer, Kaumarbhritya Department, MSDS Ayurvedic Medical College \& Hospital, Farrukhabad, Uttar Pradesh, India.

4. Associate Professor, Kaumarbhritya Department, IPGT \& RA, Jamnagar, Gujarat, India.

5. Professor, Kaumarbhritya Department, IPGT \& RA, Jamnagar, Gujarat, India.

\section{Manuscript Info}

Manuscript History

Received: 16 October 2018

Final Accepted: 18 November 2018

Published: December 2018

Key words:-

Scabies, Pama, Kushtha.
Abstract

Aim: Skin disease has a high prevalence throughout the world. Scabies is contagious and can spread quickly through close physical contact so it is an acute communicable disease. It is highly prevalent in young children.The present study is aimed to show the effect of Polyherbal formulation on scabies in children.

Backgrounds: Scabies is characterized by nocturnal itching, vesicular or pustular eruptions, with small red bumps and blisters. According to Ayurveda Scabies can be correlated to Pama. Pama is one of the eighteen types of Kușththa ("Skin Disease"), according to the Charaka Samhita (ChikitsaSthana) which is caused by vitiation of Kapha and Pitta Dosha.

Case Description: A 6 years old male patient brought by his father from Kutchh district of Gujarat in OPD of Kaumarbhritya department IPGT \& RA with complaints of itching in between the fingers of both the hands, wrists and forearms since 2 years. On local examination, vesiculopustular lesions were present along with dry scaly patches over both the hands, wrists and forearms. Effect of the treatment was assessed on the basis of clearance of lesion and relief from itching.

Conclusion: After intervention of the Polyherbal formulation for one month, there was a marked improvement in symptoms like itching, scaling, and discharge. So, it can be said that Ayurveda has a better remedy for skin related complaints than other contemporary sciences.

Copy Right, IJAR, 2017,. All rights reserved.

\section{Introduction:-}

The human skin is the outer protective covering of the body. Children have thinner and more delicate skin than adults, so it's more sensitive to irritation. Children used to play or stay in groups either in school or at home and unable to maintain their hygiene so they are easily victimized by different skin infections. Scabies is a parasitic infestation of the skin that is caused by the bite of female itch mite "Sarcoptesscabiei" ${ }^{[1]}$ In infants and young children, common sites of infestation include the scalp, face, neck, palms of the hands and soles of the feet. Lesion distribution and intractable pruritus that is worsen at night as well as scabies symptoms in close contacts helps in

Corresponding Author:-Vishal Prajapati.

Address:-PhD Scholar, Kaumarbhritya Department, IPGT \& RA, Jamnagar, Gujarat, India. 
diagnosis of scabies. ${ }^{[2]}$ Treating scabies in infants and children is challenging. Many drugs used in adults cannot be used in children because of diverse safety profiles. ${ }^{[3]}$ Many agents, most of which are topical, have been used to treat scabies, including Sulfur, Gamma benzene hexachloride (lindane), Crotamiton, Benzyl benzoate, Malathion, Ivermectin, and Permethrin. ${ }^{[4]}$ According to Ayurveda Scabies can be correlated to Pama. Pama is one of the eleven types of Kshudra Kuștha ("Minor skin disease"), according to the Charaka Samhita (Chikitsa Sthana) which is caused by vitiation of Kapha and Pitta Dosha ${ }^{[5]}$ Pama-kuștha is characterized by extreme itchy eruptions of white, reddish or black color seen over Sphika (Buttocks), Pani- Pada (Hands \& Foot), Kurpara (Forearm or elbow region). Diagnosis was based upon signs and symptoms of Pama Kushta such asToda (Pain), Kandu (Itching), Daha (Burning sensation), Pitika (Burrows), Srava (Discharge). ${ }^{[6],[7],[8]}$ The main aim of treatment was to purify the blood and bring out the toxins from the bloodstream and locally to pacify the symptoms like itching and lesions. Also personal hygiene and pathya-apathya i.e. dietary modifications were a very necessary part of the treatment.

\section{Materials and Methods:-}

Place of study;-

OPD Kaumarbhritya department, Institute of Postgraduate Teaching\& Research in Ayurveda Hospital, Jamnagar, Gujarat, India, 361008.

\section{Case Report:-}

A boy aged 6 years old from Kutch district of Gujarat with Registration no. PG18036050 came with his father to OPD of Kaumarbhritya department IPGT \& RA Hospital, Jamnagar on $24^{\text {th }}$ April 2018 at around 12 pm with the chief complaints of :-

1. Lesions over both hands, wrists and forearms

2. Itching in between the fingers

3. Itching intensifies during night time

4. Some type of discharge from rashes after itching

5. After healing of rashes, scaling occurs

Patient had above symptoms since last 2 years.

\section{On Examination:-}

1. Papulo-vesicular lesions with discrete presentation and distributed bilaterally over hands, wrists \& forearms.

2. Multiple erythematous papules, Round shaped with a well-defined border measuring from 0.1 to $0.2 \mathrm{~cm}$ in diameter, with no scales.

3. Multiple spherical vesicles with a size range measuring from 0.2 to $0.3 \mathrm{~cm}$ in diameter with erosion that has already healed and crusted.

\section{History of present illness:-}

According to his Father, patient was asymptomatic 2 years back. But since then patient had developed few rashes in between the fingers and started itching. This itchiness started from his fingers first which widespread to his wrist, forearm within last 12-18 months. Furthermore, he said that the itchiness worsens at night and his sleep was disturbed by intense pruritus. History of pyrexia was denied.They had consulted to allopathic doctor and taken treatment for the same and got relief for some months but again rashes \& itching in between the fingers started. Hence they came to Institute of Postgraduate Teaching\& Research in Ayurveda Hospital, Jamnagar, Gujarat, India for management.

\section{Past History:-}

Not significant

\section{Family History:-}

Previously, his elder brother had experienced the same complaint. Also, he had a history of sharing the same room and bed with his brother.

Personal History:-

Table 1:-Personal History

\begin{tabular}{|l|l|l|l|}
\hline Name: XYZ & Appetite: Moderate & Bowel: Irregular & Wt.: $20 \mathrm{~kg}$ \\
\hline
\end{tabular}




\begin{tabular}{|l|l|l|l|}
\hline Age/Sex: 6 yrs/M & Dietary habits: Veg. & Bladder: Regular & Ht.: $108 \mathrm{cms}$. \\
\hline Habitat: Rural & Prakriti: Kapha-Pitta & Sleep: Disturbed & BMI: $17.1 \mathrm{Kg} / \mathrm{m}^{2}$ \\
\hline Occupation: Student & Agni: Vishamagni & Bala: Madhyam & $\begin{array}{l}\text { Immunization: Proper } \\
\text { as per age }\end{array}$ \\
\hline SES: Lower-middle & Kostha: Madhyam & Addiction: None & $\begin{array}{l}\text { Growth } \\
\text { \&Development: Proper } \\
\text { as per age }\end{array}$ \\
\hline
\end{tabular}

Ashtavidha Pariksha:-

Table 2: Ashtavidha Pariksha

\begin{tabular}{|l|l|}
\hline Nadi (Pulse): 78/ min. & Shabda (Speech): Clear \\
\hline Mala (Bowel): mild constipation & Sparsha (Touch): Normal \\
\hline Mutra (Bladder): Normal & Drika (Eyes): Normal \\
\hline Jivha (Tongue): slightly coated & Akriti (Built): Madhyam \\
\hline
\end{tabular}

Treatment Plan:-

Patient was treated on OPD basis.

Selected Polyherbal formulation for internal use:-

Anubhuta Yoga - (For Internal Use)

Table 3:-Dose, Route, Kala (Drug administration time) and Anupana (Vehicle) of drugs used

\begin{tabular}{|c|c|c|c|c|}
\hline Name of medicine & Dose & Route & Kala & Anupana \\
\hline Balachaturbhadra Churna & $250 \mathrm{mg}$ & \multirow{6}{*}{ Oral } & \multirow{6}{*}{$\begin{array}{c}\text { Adhobhakta } \\
\text { (After Meal) } \\
2 \text { time/day }\end{array}$} & \multirow{6}{*}{ Madhu (Honey) } \\
\hline Khadir Churna & $500 \mathrm{mg}$ & & & \\
\hline Nimba Churna & $250 \mathrm{mg}$ & & & \\
\hline Amalaki Churna & $250 \mathrm{mg}$ & & & \\
\hline Arogyavardhini Rasa & $60 \mathrm{mg}$ & & & \\
\hline Gandhaka Rasayana & $60 \mathrm{mg}$ & & & \\
\hline
\end{tabular}

Duration: 28 Days of treatment with regular follow up every 7 days

Criteria for selection of internal Polyherbal formulation:-

Table 4:-Ingredients of preparation used for oral administration with their use ${ }^{[9],[10],[11],[12],[13],[14],[15],[16],[17],[18]}$

\begin{tabular}{|c|c|c|}
\hline Name of medicine & Ingredients & Properties\& Uses \\
\hline Balachaturbhadra Churna & Musta, Pippali, Ativisha, Karkatshringi & Deepana, Pachana, Tridoshahar \\
\hline Khadira Churna & 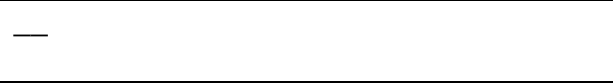 & $\begin{array}{l}\text { Kandughna, Kushthaghna, } \\
\text { Vranaropak }\end{array}$ \\
\hline Nimba Churna & - & $\begin{array}{l}\text { Kapha-Pitta Shamak, } \\
\text { Raktadoshahar, Vranaropaka, } \\
\text { Kushtaghna }\end{array}$ \\
\hline Amalaki Churna & - & $\begin{array}{l}\text { Rasayana, Sroto-shodhaka, } \\
\text { Anulomaka, Deepana, Pachana. }\end{array}$ \\
\hline Arogyavardhini Rasa & $\begin{array}{l}\text { Gandhaka, Parada, Lohabhasma, } \\
\text { Abhrakabhasma, Tamrabhasma, Shilajatu, } \\
\text { Guggula, Chitraka, Kutaki, Triphala, } \\
\text { Nimbapatra }\end{array}$ & $\begin{array}{l}\text { Deepana, Pachana,Pittarechaka, } \\
\text { Hepatoprotective }\end{array}$ \\
\hline Gandhaka Rasayana & $\begin{array}{l}\text { Shuddha Gandhak, Goksheer, Chaturjata, } \\
\text { Guduchi, Pathya, Dhatri, Aksha, } \\
\text { Bhringaraja, Aardraka }\end{array}$ & $\begin{array}{l}\text { Raktashodhaka, Vranaropaka, } \\
\text { Kandughna, Kushthaghna, Twachya }\end{array}$ \\
\hline
\end{tabular}

Selected External Ayurvedic Drugs:-

Table 5:-Dose, Duration of drugs used externally

\begin{tabular}{|l|l|l|}
\hline \multicolumn{1}{|c|}{ Name of medicine } & Dose & Duration \\
\hline Panchawalkala Kwatha Churna & $5 \mathrm{gm}(2$ times /day $)$ & 28 Days \\
\hline Gandhaka Malhara & $5 \mathrm{gm}(2$ times /day $)$ & 28 Days \\
\hline
\end{tabular}


Criteria for selection of External medicines:-

Table 6:-Ingredients of external medicines with their uses [19],[20],[21],[22]

\begin{tabular}{|l|l|l|}
\hline Name of medicine & Ingredients & Properties \& Uses \\
\hline Panchawalkala Kwatha Churna & $\begin{array}{l}\text { Vata, Udumbar, Ashwatha, Parisha, } \\
\text { Plaksha }\end{array}$ & $\begin{array}{l}\text { Shodhana (Cleaning), Ropana } \\
\text { (Healing) }\end{array}$ \\
\hline Gandhaka Malhara & $\begin{array}{l}\text { Sikthataila, Gandhaka,Haratala, Girisindura, } \\
\text { Tankana Bhasma, Karpura }\end{array}$ & Vranaropaka \\
\hline
\end{tabular}

\section{Preparation of Kwatha:-}

Take Kwatha Churna (Coarse Powder) in above mentioned quantity then add 8 times of water and allow the herbs to completely get soaked in water for 1-2 hours. Then start boiling this mixture in a wide mouth container in mild fire. Keep on stirring the contents with ladle. Boil this till it reduces to one fourth quantity after that filter it across a clean cloth immediately and use when it is mild hot.

All the internal and external medicines used in this case were prepared in the Pharmacy, Gujarat Ayurved University, Jamnagar, Gujarat, India, so as to assure authenticity of drugs.

Ahara and Vihara (Diet and mode of life) advised during treatment:-

Table 7:-Pathya- Apathya

\begin{tabular}{|l|l|}
\hline Pathya (Regimen to follow) & Apathya (Regimen to be restricted) \\
\hline Ahara & Ahara \\
\hline $\begin{array}{l}\text { Green gram, Rice, Wheat, Green vegetables, Fruits, } \\
\text { Lukewarm water, Ginger water etc. }\end{array}$ & $\begin{array}{l}\text { Ice cream, Cold drinks, Curd, Bread, Toast, Jam, Sauce, } \\
\text { Non-Veg, Egg, Oily substances like chips etc, Fast food, } \\
\text { Fermented foods,Sweet and sour taste foods,Milk, } \\
\text { Yoghurt, Pickles etc. }\end{array}$ \\
\hline Vihara & Vihara \\
\hline $\begin{array}{l}\text { Adequate sleep at night (8 hours), Maintain the personal } \\
\text { hygiene, Clothes, bed linen, towels should be boiled and } \\
\text { changed frequently, While bathing put few leaves of } \\
\text { neem in the hot water. }\end{array}$ & $\begin{array}{l}\text { Night awaking (Ratri Jagarana), Day sleeping } \\
\text { (Diwaswapa) }\end{array}$ \\
\hline
\end{tabular}

Assessment of effect of treatment on the basis of grading pattern of subjective and objective parameters:-

Table 8:-Grading pattern of subjective and objective parameters

\begin{tabular}{|l|l|}
\hline Toda (Pain) & Grade \\
\hline Severe Toda with disturbed sleep & 03 \\
\hline Moderate Toda without disturbed sleep & 02 \\
\hline Mild or occasional Toda & 01 \\
\hline No Toda & 00 \\
\hline Kandu (Itching) & Grade \\
\hline Continuous itching which interferes daily work or sleep & 03 \\
\hline Continuous itching without disturbed daily work or sleep & 02 \\
\hline Mild or occasionally itching & 01 \\
\hline No itching & 00 \\
\hline Pitika (Burrows) & Grade \\
\hline Many or uncountable Pitikas in the whole affected area & 03 \\
\hline 5-10 Pitikas in one square cm & 02 \\
\hline Pitika almost disappear but discoloration persists & 01 \\
\hline No Pitika & 00 \\
\hline Daha (Burning sensation) & Grade \\
\hline Continuous Daha with disturbed sleep & 03 \\
\hline Continuous Daha without disturbed sleep & 02 \\
\hline Occasional Daha & 01 \\
\hline No Daha & 00 \\
\hline
\end{tabular}




\begin{tabular}{|l|l|}
\hline Srava (Burning sensation) & Grade \\
\hline Srava without itching & 02 \\
\hline Srava with itching & 01 \\
\hline No Srava with or without itching & 00 \\
\hline
\end{tabular}

Observations \&Results:-

Table 9:-Progress of Treatment

\begin{tabular}{|l|c|c|c|c|c|}
\hline $\begin{array}{l}\text { Follow up visits } \\
\text { (Days) }\end{array}$ & $\begin{array}{c}\text { Toda (Pain) } \\
\text { Grade }\end{array}$ & $\begin{array}{c}\text { Kandu (Itching) } \\
\text { Grade }\end{array}$ & $\begin{array}{c}\text { Pitika } \\
\text { (Burrows) } \\
\text { Grade }\end{array}$ & $\begin{array}{c}\text { Daha (Burning } \\
\text { sensation) } \\
\text { Grade }\end{array}$ & $\begin{array}{c}\text { Srava } \\
\text { (Discharge) } \\
\text { Grade }\end{array}$ \\
\hline After 7 days & 1 & 3 & 2 & 3 & 1 \\
\hline After 14 days & 1 & 2 & 2 & 2 & 1 \\
\hline After 21 days & 0 & 1 & 1 & 1 & 0 \\
\hline After 28 days & 0 & 0 & 0 & 0 & 0 \\
\hline
\end{tabular}

Assessment of signs and symptoms of the patient regarding Pama was done during each follow up i.e. after every 7 days. Above table shows that there is significant relief in all signs and symptoms of Pama ( Scabies) after about 1 month of intervention. It means selected management of Pama is effective.

\section{Discussion:-}

As per Ayurveda literatures, Pama Kushtha is Pitta-Kapha dominant Vyadhi and Kandu, Srava, Pidika etc. are the clinical features. The Deepan, Pachana, Rukshana, Swedana are the basis of Shamana Chikitsa. Drugs in Anubhuta yoga were having mainly Tikta, Kashaya Rasa, Ruksha, Laghu Guna, Sheeta Virya, Katu Vipaka hence they are Kapha-Pitta shamaka and acted as Vranaropaka, Shonitasthapaka, Kushthaghna. Whereas Arogyavardhinirasa helped to improve the liver function by removing the toxins, Shoshan of excess Snigdha Dravya, Pachana of Drava and Kleda, Raktavardhana. Gandhakarasayana has Raktashodhaka, Vranaropaka, and Twachya Property. Externally used drugs were Panchawalkal Kwath for Shodhana (cleaning), Ropana (healing) of lesions, after external washing of lesion areas Gandhaka Malahara was used topically which has Vranaropaka, Twachya property, and it is also a drug of choice for Pama. Along with above medications, Pathya-apathya and hygiene maintenance were also advised to patient. Child has followed the treatment protocol and Pathya-apathya properly and responded very well with treatment.

\section{Conclusion:-}

Hence it is concluded that external use of Panchvalkala Kwath and Local Application of Gandhaka Malhar along with internal use of Polyherbal formulation and proper hygiene maintenance are highly effective in the management of Scabies (PamaKushtha).

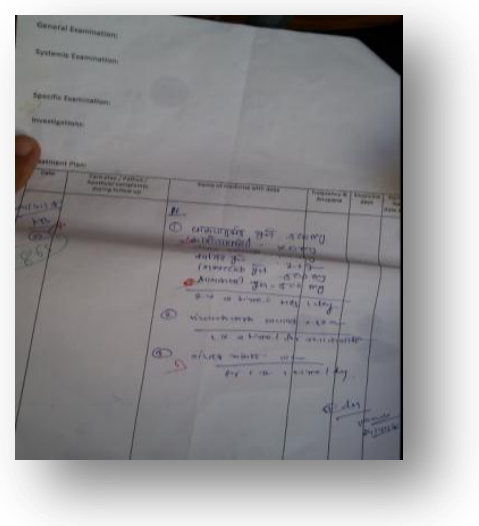

Fig 1:- OPD Case Paper

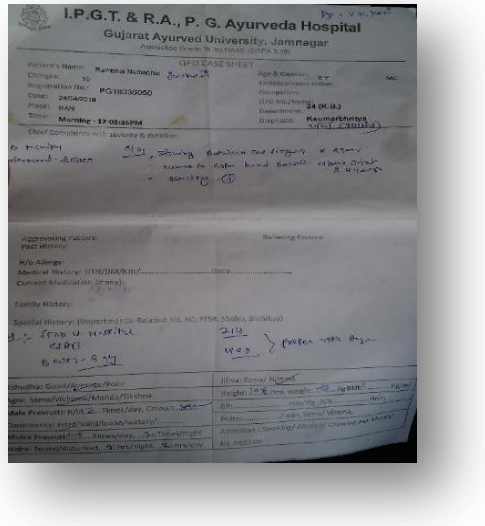

Fig 2:- Treatment on $1^{\text {st }}$ consultation

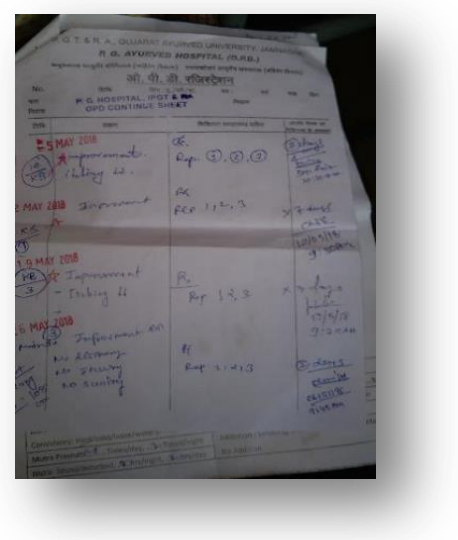

Fig 3:- Regular follow ups for 1 month 

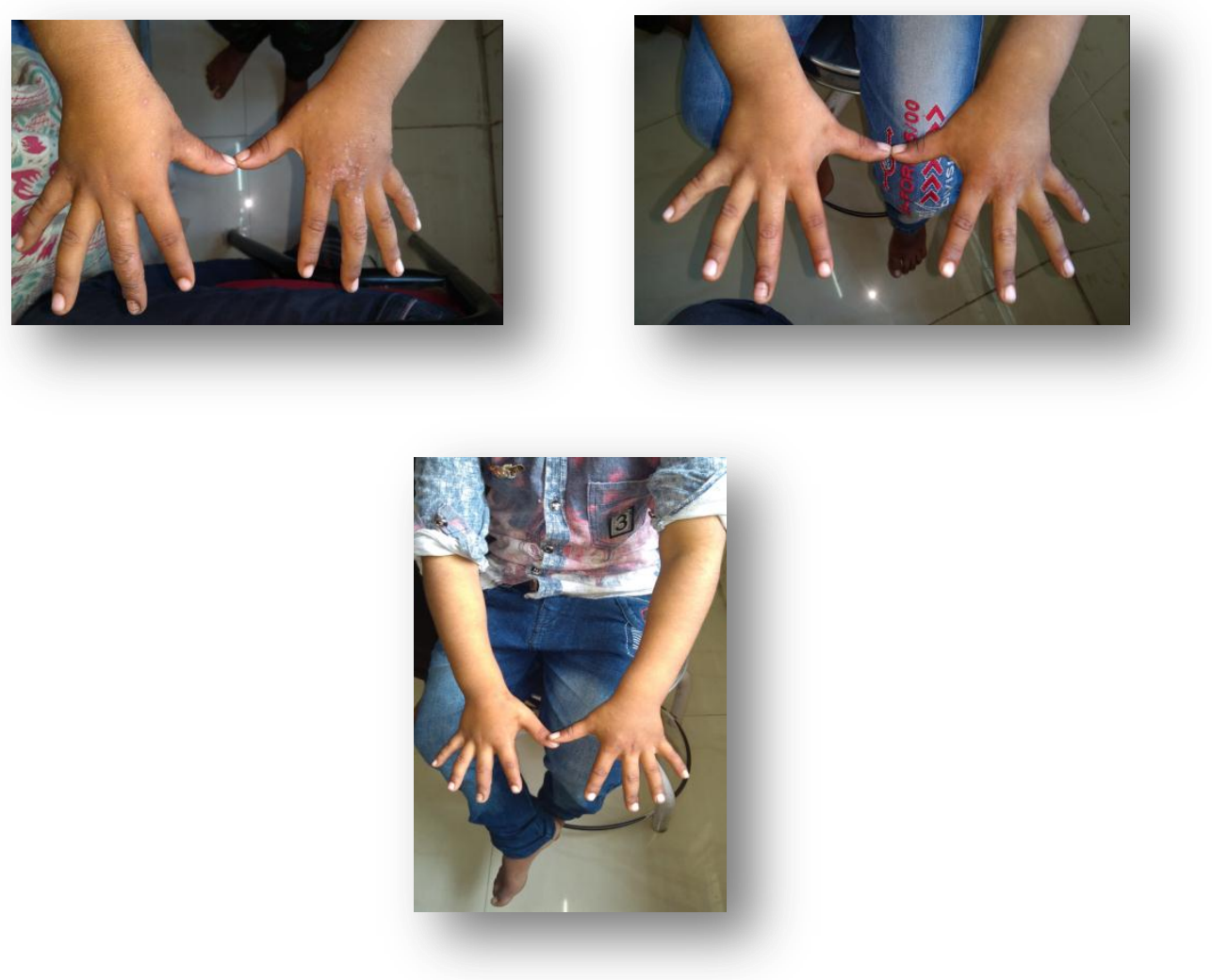

Fig 4:-Clinical Picture before treatment.

Fig 5:-Clinical Picture at the Midpoint of Treatment.

Fig 6:-Clinical Picture at the End of the treatment.

\section{Acknowledgement:-}

Special thanks to Dr. ANUP THAKAR (Director, IPGTRA), Prof. K. S. PATEL (HOD, KB Department, IPGTRA), Dr. V. K. KORI (Asso. Professor, KB Department, IPGTRA).

\section{Refrences:-}

1. Andrews RM, McCarthy J, Carapetis JR, Currie BJ. Skin disorders, including pyoderma, scabies and tinea infections. Pediatr Clin North Am. 2009;56(6):P. 1421-40.

2. https://emedicine.medscape.com/article/1109204-clinical

3. Karthikeyan K. Scabies in children. Arch Dis Child Educ Pract Ed. 2007;92(3):e65-9.

4. Currie BJ, McCarthy JS. Permethrin and ivermectin for scabies. N Engl J Med. 2010;362(8):P. 717-25.

5. Shukla V, Tripathi R D, Vaidyamanorama hindi commentary, Charaka Samhita of Agnivesha, Chaukhambha Sanskrit Pratishthan, Delhi,2009, Vol. II, Ch. Chi. 7/30, P. 185.

6. Shukla V, Tripathi R D, Vaidyamanorama hindi commentary, Charaka Samhita of Agnivesha, Chaukhambha Sanskrit Pratishthan, Delhi,2009, Vol. II, Chikitsasthan, Chapter no.7 Verse 25, P. 184-185.

7. Sharma A R, Sushrutavimarshini Hindi commentary, Sushruta Samhiata of Sushruta, Chaukhambha Surbharati Prakashan, Varanasi, 2010, Vol. I, Nidanasthan, Chapter 5 Verse 14, P. 497.

8. Gupta Atrideva, Upadhyaya Yadunandana, Vidyotini Hindi Commentary, Ashtangahridayama of Vagbhata, Chaukhambha Prakashan, Varanasi, 2016, Nidanasthan chapter 14, Verse 28, P. 371.

9. Govindadas, Bhaisajya Ratnavali, Balaroga Chikitsa Prakarana, Chaukhambha Bharati Academy, Varanasi,2002, Verse 39, P. 747

10. Khare CP. Indian medicinal plant. An illustrated dictionary. Springer-Verlag Berlin @ 2002 P. 447-449

11. Database in Medicinal Plants used in Ayurveda, CCRAS, Dept of AYUSH, 2002, Volume 3;P. 471

12. Ayurvedic Pharmacopeia of India, Dept. of AYUSH, 2007, Part I, Volume 4;P. 105 
13. Ayurvedic Pharmacopoeia of India, Published by Ministry of Health \& Family welfare, Edition 1, Year of publication 2003,Part 1, Volume 1, P. 66

14. Dr. J.1.n sastry, Dravyaguna Vijyana, chaukhambha orientalia,Varanasi, second Edition-2005, P. 123.

15. Sharma P. V., Dravyaguna-Vijnana, Varanasi: Chaukhambha Bharati Academy, VOL. II, 2011; 341:P. 758760.

16. Ambikadatta Shastri, Vagbhattacharya, Chaukhambha Bharati Academy, Varanasi, 2010, Chp. No.20, Verse 87-93, P. 400.

17. Joshi Y G. Textbook of Kayachikitsa, Chapter no. 79, Shri Ganesh Publisher, Pune, 2010, P. 651.

18. Ayurveda Prakash of Acharya Shri Madhava, Edited with the Arthavidyotini \& Arthaprakashini Sanskrit \& Hindi commentaries by Vaidya Gulraj Sharma Mishra, Chaukhambha Bharati Academy, Varanasi, Verse 4647, P. 268.

19. Pandit Parashuram shastri Vidyasagar, Sharangadhar Samhita, Chaukhambha Prakashan, Varanasi,2013, Madhyam khanda, verse 149, P. 164

20. Khadkutkar DK, Kanthi VG. Therapeutic uses of Panchvalkala in different forms-A review. Ayurlog Natl J Res Ayurveda Sci.2014;2:P. 1-5

21. Sadananda Sharma, Rasa Tarangini, Chaukhambha Bharati Academy, Varanasi,2014, Gandhak Vigyaniya, P. 186

22. Apturkar N C, Deshpande A, Kothari N, Karare P. Effect of gandhaka malhara on padadari: A case study. WJP MR, 2018, 4(10), P. 148-151. 